\title{
Patterns of plasma LH, FSH, oestradiol and corticosteroids from birth to the first oestrous cycle in Meishan gilts
}

\author{
A. Prunier ${ }^{1}$, M. Chopineau ${ }^{2}$, A. M. Mounier ${ }^{1}$ and P. Mormède ${ }^{3}$ \\ ${ }^{1}$ Station de Recherches Porcines, INRA, F-35590 Saint Gilles, France; ${ }^{2}$ Station de Physiologie de la \\ Reproduction, INRA, F-37380 Nouzilly, France; and ${ }^{3}$ Laboratoire de Neurobiologie du Comportement, \\ F-INRA-INSERM U259, F-33077 Bordeaux Cédex, France
}

\begin{abstract}
Hormonal changes associated with pubertal development in a breed of pig exhibiting early puberty were determined. In Expt 1, blood from prepubertal Meishan gilts was collected at about $1(n=5), 10(n=5), 20(n=4), 30(n=5), 50(n=5), 70(n=10), 80(n=10)$ and $90(n=7)$ days of age. In Expt 2, females were sampled between 99 and 116 days of age before $(n=16)$ or during $(n=9)$ the first oestrous cycle. Serial blood samples were collected through a jugular catheter at 20 min intervals. In Expt 2, age at puberty was determined by daily examination for oestrus and weekly evaluation of plasma progesterone and found to occur at 111 days of age. Hormone profiles determined at least 19 days before the first oestrus were grouped to constitute a prepubertal stage. In Expt 1, mean concentration of LH was high at 1 day of age, significantly lower at 10 days and showed nonsignificant variations until 90 days. Frequency of LH pulses increased between 10 and 50 days $(0.42$ versus 0.85 pulse $\left.h^{-1}, P<0.05\right)$, decreased between 50 and 70 days $\left(0.49\right.$ pulse $h^{-1}$, $P<0.05)$ and remained low thereafter. Amplitude of LH pulses was high between $I$ and 30 days and declined progressively until 80 days. Mean concentration of FSH was high between 1 and 20 days and decreased progressively until 80 days $\left(7.2\right.$ and $2.3 \mathrm{ng} \mathrm{ml}^{-1}$, respectively, at 20 and 80 days, $P<0.05$ ). Concentrations of oestradiol and corticosteroids were highest at day 1 and showed nonsignificant fluctuations between 10 and 90 days. The concentration of corticosteroids was higher in the morning than in the afternoon $(P<0.05)$ whatever the age. In Expt 2, comparisons with the prepubertal stage showed a mild increase in number of LH pulses $(P=0.07) 11-13$ days before puberty, an increase in mean $(P=0.07)$ and baseline concentration $(P<0.05)$ of $\mathrm{LH}$, in oestradiol concentration $(P<0.05)$ and a decrease in morning concentration of cortisol $(P=0.06) 4-6$ days before puberty. After puberty, concentrations of $\mathrm{LH}$ (mean), FSH and progesterone were higher, whereas morning cortisol was lower at the beginning of the luteal phase than during the prepubertal stage $(P<0.05)$. At the end of the luteal phase, the only differences with the prepubertal stage were higher progesterone concentration and amplitude of LH pulses. Hormonal changes in Meishan gilts therefore show a similar pattern to that observed in European breeds of pig with a perinatal, an infancy, a juvenile and a waiting phase. Four to 13 days before puberty an increase in $\mathrm{LH}$ and a decrease in corticosteroid secretions are probably involved in stimulation of follicular growth which leads to the first ovulation.
\end{abstract}

\section{Introduction}

Genotype plays an important role in the determination of age at puberty. In female pigs, the first oestrus and ovulation normally occur between 5 and 8 months of age in European breeds (Christenson and Ford, 1979; Hughes, 1982) and at about 3 months of age in the Chinese Meishan breed (Cheng, 1983; Legault and Caritez, 1983). This latter breed is, therefore, a useful model to investigate the endocrine mechanisms that control onset of puberty. In European Large White gilts, pubertal at about 8 months of age, four phases of development related to ovarian development and gonadotrophin secretions have been

Received 19 February 1992. described between birth and puberty (Camous et al., 1985): a perinatal phase (first month of life), an infancy period (second month of life), a phase of initiation of sexual development (third to fifth months of life) and a waiting period (sixth month of life until puberty). Antral follicles and follicles larger than $1 \mathrm{~mm}$ in diameter appear earlier in Meishan than in Large White females (at about 30 and 60 days versus 70 and 90 days, respectively) (Mauléon, 1961; Cheng, 1983; Prunier et al., 1987; Miyano et al., 1990). To our knowledge, the patterns of gonadotrophin and oestrogen secretions during sexual maturation have not been described in Meishan gilts.

A role for adrenal hormones in the sexual maturation of gilts has often been evoked even though the mechanisms by which 
they are effective are unknown. In fact, management practices such as mixing, relocation and transportation of gilts, which induce an acute stress response, characterized by a rapid increase in plasma cortisol concentrations (Dantzer and Mormède, 1983), trigger the onset of puberty in European gilts (Du Mesnil Du Buisson and Signoret, 1962). Moreover, puberty is delayed in adrenalectomized gilts and advanced in intact gilts treated with synthetic glucocorticoids (Killian et al., 1987). Finally, it has been shown that corticosteroids affect basal or GnRH-stimulated LH secretion (Fonda et al., 1984; Pearce et al., 1988) in European gilts. Development of the circadian thythm of corticosteroids has recently been investigated in gilts from a European breed (Evans et al., 1989). This study indicated that the circadian variations in blood concentrations undergo gradual modifications reaching adult profiles at, or shortly before, puberty. As far as we know, the development of corticosteroid secretion has not yet been described in Meishan gilts.

The objective of the present study was to describe the patterns of plasma LH, FSH, oestradiol and corticosteroids during sexual maturation of Meishan gilts.

\section{Materials and Methods}

\section{Animals}

Twenty gilts from five different litters born in December or April were used in Expt 1. Animals were maintained under natural light conditions throughout the experiment. Weaning was carried out between 21 and 23 days of age. From 50 days of age, animals were kept in individual pens and fed ad libitum with a standard diet. Ovulation was detected by collecting blood samples once a week from 80 days and a direct radioimmunoassay (Terqui and Thimonnier, 1974) was performed on plasma to determine whether the concentration of progesterone was higher than $5 \mathrm{ng} \mathrm{ml}^{-1}$.

Fifteen gilts from four different litters born in June were used for Expt 2 and kept under the same conditions as animals in Expt 1. From 60 days of age, gilts were checked for onset of oestrus twice a day with pubertal boars. From 80 days, plasma progesterone was evaluated once a week. Age at puberty was defined as the age on the first day of the first oestrus accompanied by ovulation (day 0 ). Females were killed at 130 days of age.

\section{Collection of blood samples}

Serial blood samples were collected via an indwelling Silastic catheter (Table 1). At each age, one or two animals from each litter were sampled. In one-day-old piglets, a catheter was inserted into one umbilical artery immediately after birth, as described by Le Dividich et al. (1991). In older females, the catheter was inserted into one jugular vein under general anaesthesia ( $1.51 \mathrm{~min}^{-1} \mathrm{O}_{2}$ : halothane 96:4, vol:vol). Catheters were inserted at least 3 days before blood collection started. Samples were taken every $20 \mathrm{~min}$, beginning at 09:00 h, for $7 \mathrm{~h}$ for females up to 10 days old and for $8 \mathrm{~h}$ in older females. The last samples taken between $16: 30 \mathrm{~h}$ and $17: 00 \mathrm{~h}$ on day 1 and day 10 were used for corticosteroid determination; the total
Table 1. Age and body weight (mean \pm SEM) of gilts at time of collection of blood samples

\begin{tabular}{lccc}
\hline Age & Body weight & Number of \\
$(\mathrm{kg})$ & hormone profiles \\
\hline
\end{tabular}

Experiment 1

$\begin{array}{rrrr}1 & 1-2 & 0.9 \pm 0.1 & 5 \\ 10 & 9-10 & 1.9 \pm 0.2 & 5 \\ 20 & 16-20 & 3.8 \pm 0.4 & 4 \\ 30 & 30-31 & 6.9 \pm 0.7 & 5 \\ 50 & 50-51 & 12.4 \pm 1.3 & 5 \\ 70 & 71-72 & 22.4 \pm 1.6 & 10 \\ 80 & 79-80 & 27.3 \pm 1.9 & 10 \\ 90 & 87-90 & 28.5 \pm 2.5 & 7\end{array}$

Experiment 2

$99-116 \quad 31.7 \pm 0.7$

25

volume of blood drawn per piglet did not exceed $15 \mathrm{ml}$. Gilts were sampled two or three times with at least 9 days between samples. Plasma was collected after centrifugation $(10 \mathrm{~min}$ at $1600 \mathrm{~g}$ ) and stored at $-20^{\circ} \mathrm{C}$ until assayed.

\section{Assays}

Concentrations of LH and FSH in plasma were measured by previously validated homologous radioimmunoassays (Camous et al., 1985). LH was measured in all samples and FSH in samples collected at hourly intervals. For each experiment, both hormones were measured in single assays. Sensitivities were 0.7 and $0.5 \mathrm{ng} \mathrm{ml}^{-1}$ for $\mathrm{LH}$ and $\mathrm{FSH}$, respectively, and intra-assay coefficients of variation were $8 \%$ at $1.7 \mathrm{ng} \mathrm{LH} \mathrm{ml}^{-1}$ and at $2.5 \mathrm{ng}$ $\mathrm{FSH} \mathrm{ml} \mathrm{m}^{-1}$. Oestradiol was measured by radioimmunoassay (Thibier and Saumande, 1975) in pools made up of aliquots of all samples from one animal within a series of blood samples. Extraction procedures were slightly modified; $1 \mathrm{ml}$ of plasma was extracted once with $5 \mathrm{ml}$ of cold diethyl ether. The sensitivity of the assay was $5 \mathrm{pg} \mathrm{ml}^{-1}$; intra- and interassay coefficients of variation were $5 \%$ and $25 \%$, respectively, at $410 \mathrm{pg}$ oestradiol $\mathrm{ml}^{-1}$. Corticosteroid concentrations were measured in samples taken at 09:00 h and between 16:30 h and $17: 00 \mathrm{~h}$, by a protein-binding assay after dichloromethane extraction (Mormède and Dantzer, 1978). Sensitivity of the assay was $1 \mathrm{ng}$ corticosteroids $\mathrm{ml}^{-1}$, and intra- and interassay variability averaged 7 and $10 \%$, respectively.

\section{Calculations and statistical analyses}

Pulses of LH were identified according to the method described by Merriam and Wachter (1982). For each LH profile, the number of pulses $\mathrm{h}^{-1}$, the mean concentration of all samples (mean concentration) and of interpulse samples (baseline) as well as the average amplitude of pulses (within-pulse maximal concentration minus baseline concentration) were determined. For each FSH profile, mean hormone concentration was calculated. In Expt 2, profiles were grouped according to the number 
Table 2. Plasma profiles of LH, FSH and oestradiol in Meishan gilts from 1 to 90 days of age

\begin{tabular}{|c|c|c|c|c|c|c|}
\hline $\begin{array}{l}\text { Age } \\
\text { group } \\
\text { (days) }\end{array}$ & $\begin{array}{c}\text { Plasma LH } \\
\left(\mathrm{ng} \mathrm{ml}^{-1}\right)\end{array}$ & $\begin{array}{l}\text { Baseline } \\
\text { plasma LH } \\
\left(\mathrm{ng} \mathrm{ml}^{-1}\right)\end{array}$ & $\begin{array}{l}\text { Frequency } \\
\text { of } \mathrm{LH} \text { pulses } \\
\text { (number } \mathrm{h}^{-1} \text { ) }\end{array}$ & $\begin{array}{l}\text { Amplitude } \\
\text { of LH pulses } \\
\left(\mathrm{ng} \mathrm{ml} \mathrm{ml}^{-1}\right)\end{array}$ & $\begin{array}{c}\text { Plasma FSH } \\
\left(\mathrm{ng} \mathrm{ml}^{-1}\right)\end{array}$ & $\begin{array}{c}\text { Plasma } \\
\text { oestradiol } \\
\left(\mathrm{pg} \mathrm{ml} \mathrm{m}^{-1}\right)\end{array}$ \\
\hline 1 & $3.3 \pm 0.4^{\mathrm{a}}$ & $2.7 \pm 0.3^{\mathrm{a}}$ & $0.55 \pm 0.09^{\mathrm{ab}}$ & $2.5 \pm 0.4^{\mathrm{ab}}$ & $6.4 \pm 1.8^{\mathrm{ab}}$ & $12.9 \pm 2.4$ \\
\hline 10 & $2.3 \pm 0.1^{b}$ & $1.8 \pm 0.2^{b}$ & $0.42 \pm 0.08^{\mathrm{b}}$ & $2.4 \pm 0.5^{\mathrm{ab}}$ & $5.7 \pm 2.0^{\mathrm{abc}}$ & $9.5 \pm 2.2$ \\
\hline 20 & $2.2 \pm 0.1^{b}$ & $1.4 \pm 0.1^{b}$ & $0.72 \pm 0.07^{\mathrm{ab}}$ & $2.4 \pm 0.4^{\mathrm{ab}}$ & $7.2 \pm 1.9^{\mathrm{a}}$ & $8.5 \pm 0.1$ \\
\hline 30 & $2.7 \pm 0.4^{\mathrm{ab}}$ & $1.9 \pm 0.2^{b}$ & $0.70 \pm 0.12^{\mathrm{ab}}$ & $2.7 \pm 0.5^{\mathrm{a}}$ & $4.3 \pm 0.6^{\mathrm{abc}}$ & $7.2 \pm 0.5$ \\
\hline 50 & $2.4 \pm 0.1^{\mathrm{ab}}$ & $1.9 \pm 0.1^{\mathrm{b}}$ & $0.85 \pm 0.05^{\mathrm{a}}$ & $1.4 \pm 0.1^{\mathrm{bc}}$ & $3.6 \pm 0.3^{\mathrm{abc}}$ & $6.6 \pm 0.3$ \\
\hline 70 & $2.1 \pm 0.1^{b}$ & $1.8 \pm 0.1^{b}$ & $0.49 \pm 0.04^{\mathrm{b}}$ & $1.5 \pm 0.2^{\mathrm{bc}}$ & $3.0 \pm 0.2^{\mathrm{bc}}$ & $7.9 \pm 1.7$ \\
\hline 80 & $2.1 \pm 0.1^{b}$ & $1.9 \pm 0.1^{b}$ & $0.51 \pm 0.06^{\mathrm{b}}$ & $1.1 \pm 0.1^{\mathrm{c}}$ & $2.3 \pm 0.2^{\mathrm{c}}$ & $7.5 \pm 1.2$ \\
\hline 90 & $2.2 \pm 0.1^{b}$ & $2.0 \pm 0.1^{b}$ & $0.50 \pm 0.05^{\mathrm{b}}$ & $1.0 \pm 0.1^{\mathrm{c}}$ & $1.9 \pm 0.3^{\mathrm{c}}$ & $6.9 \pm 1.1$ \\
\hline
\end{tabular}

Values are means \pm SEM.

a.b.c Means within a row with different superscripts are significantly different $(P<0.05)$.

of days from puberty. Samples from a prepubertal group were collected at least 19 days before puberty and not thereafter $(n=9)$.

All data were analysed using the Statistical Analysis System (SAS, 1985). In Expt 1, data were subjected to the general linear model analysis of variance. Main effects included in the model were age and litter. For corticosteroids, the effect of time (morning versus afternoon) and the interaction time $x$ age were introduced in the model of analysis of variance. Bonferroni's tests (SAS, 1985) were used for comparisons between means. In Expt 2, all groups were compared with the prepubertal group using Student's $t$ test.

\section{Results}

\section{Puberty attainment}

In Expt 1, none of the gilts had ovulated before collection of blood samples. In Expt 2, nine out of 15 females were pubertal before 130 days of age. Ovulation did not occur without a detected oestrus. The standing reaction in the presence of a boar was observed for 2-3 consecutive days. Age at puberty ranged between 99 and 116 days and averaged $111 \pm 4$ days (mean $\pm \mathrm{SEM}$ ). In three females, a standing response to the pressure on the back was observed 3-13 days before puberty but lasted only 1 day and was not accompanied by ovulation. In addition to the prepubertal group, there were five groups with different intervals between collection of blood samples and puberty: 11-13 days before $(n=3), 4-6$ days before $(n=4)$, 1 day after $(n=1), 4-5$ days after $(n=4), 11-15$ days after the occurrence of puberty $(n=4)$.

\section{LH profiles}

In Expt 1 , mean concentration of $\mathrm{LH}$ in plasma varied with age $(P<0.01)$; it was significantly higher at 1 than at 10,20 , 70,80 and 90 days of age and was intermediate between 30 and 50 days of age (Table 2). Baseline LH values decreased significantly between 1 and 10 days of age and did not change thereafter (Table 2). Pulses were observed at every age but their frequency showed large variations $(P<0.01$, Table 2$)$.

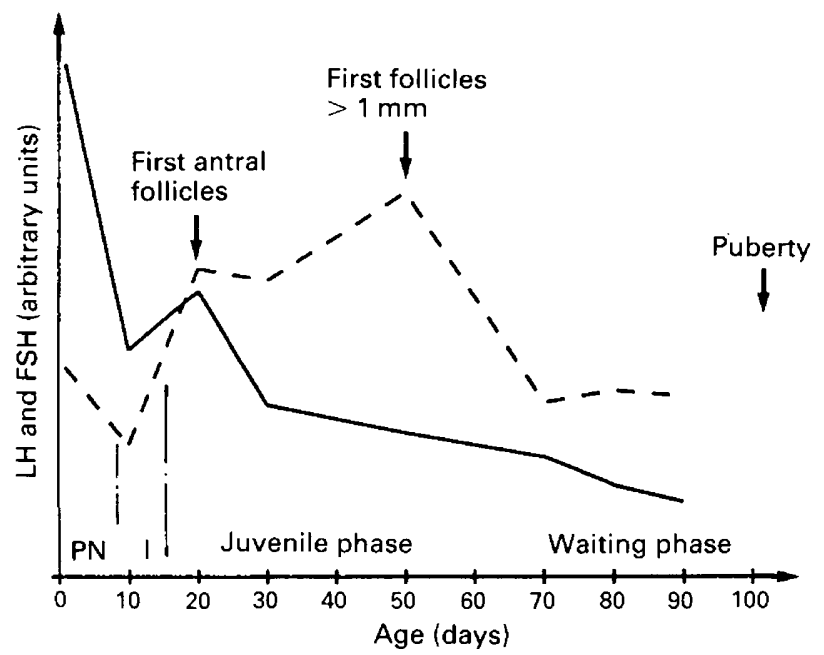

Fig. 1. Schematic variation of LH pulsatility (-- ) and FSH concentration in Meishan gilts during sexual maturation (-). PN: Perinatal; I: infancy.

Frequency of pulses increased significantly from 0.42 pulse $^{-1}$ at 10 days of age to 0.85 pulse $h^{-1}$ at 50 days of age (Table 2), declined between 50 and 70 days $\left(0.49 \pm 0.04\right.$ pulse $\left.h^{-1}\right)$ and remained low thereafter. The amplitude of the pulse was high until 30 days of age and decreased progressively until 80 days of age from $2.7 \pm 0.5 \mathrm{ml}^{-1}$ to $1.1 \pm 0.1 \mathrm{ml}^{-1}$ (Table 2; Fig. 1).

In Expt 2, number of pulses was slightly higher 11-13 days before puberty than in the prepubertal group ( $P=0.07$, Fig. 2 ). Mean and baseline concentrations were higher $4-6$ days before and 4-5 days after puberty than in the prepubertal group (Figs 2 and 3). Amplitude of pulses decreased 4-6 days before and increased 11-15 days after puberty compared with the prepubertal group $(P<0.05)$.

\section{FSH concentrations}

In Expt 1 , mean concentrations of plasma $\mathrm{FSH}$ varied with age $(P<0.01$, Table 2$)$. It was high until 20 days of age and 


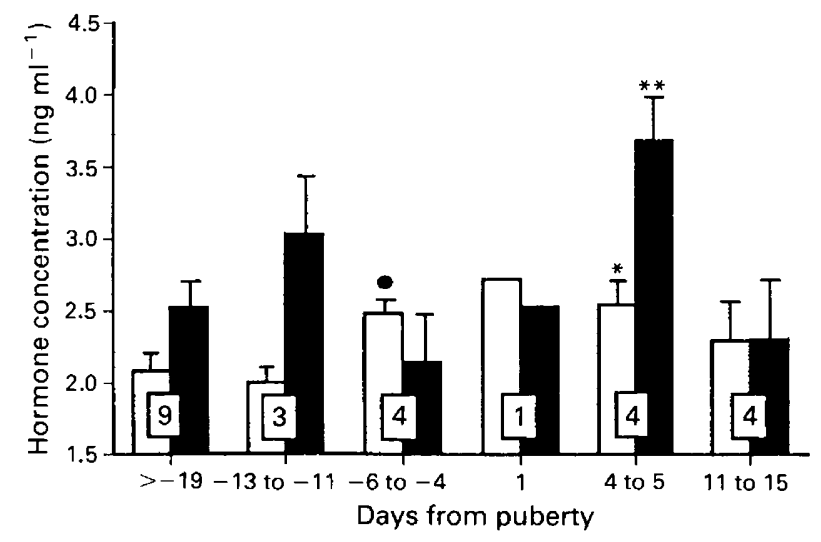

Fig. 2. Variation in mean concentration of $(\square)$ LH and ( $\square$ ) FSH in plasma of Meishan gilts around puberty. Number of gilts per stage is indicated at the bottom of bars. From days -13 to -4 and days 4 to 15 , means were compared with the prepubertal stage $(>-19$ days from puberty) and $0,{ }^{*},{ }^{* *}: P=0.07, P<0.05$ and $P<0.01$, respectively.

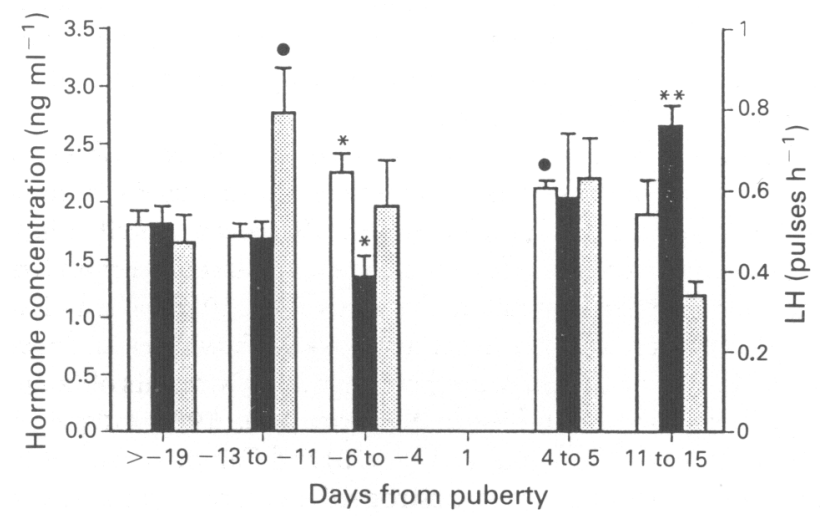

Fig. 3. Characteristics of LH profiles ( $\square$ baseline concentration, amplitude and 0 frequency of pulses) in Meishan gilts around puberty. From days -13 to -4 and days 4 to 15 , means were compared with the prepubertal stage ( $>-19$ days from puberty) and $\bullet$, ${ }^{*},{ }^{* *}: P=0.06, P<0.05$ and $P<0.01$, respectively.

decreased progressively between 20 and 80 days of age from $7.2 \pm 1.9 \mathrm{ng} \mathrm{ml}^{-1}$ to $2.3 \pm 0.2 \mathrm{ng} \mathrm{ml}^{-1}$ (Table 2).

In Expt 2, concentration of FSH was higher 4-5 days after puberty than in the prepubertal group $(P<0.01$, Fig. 2$)$.

\section{Oestradiol concentrations}

In Expt 1, plasma concentration of oestradiol did not vary significantly with age even though large fluctuations were observed (Table 2). In Expt 2, a significant increase was observed 4-6 days before puberty in comparison with the prepubertal group (Fig. 4).

\section{Corticosteroid concentrations}

In Expt 1, there was no interaction between time and age $(P>0.1)$ for the concentration of plasma corticosteroids, which

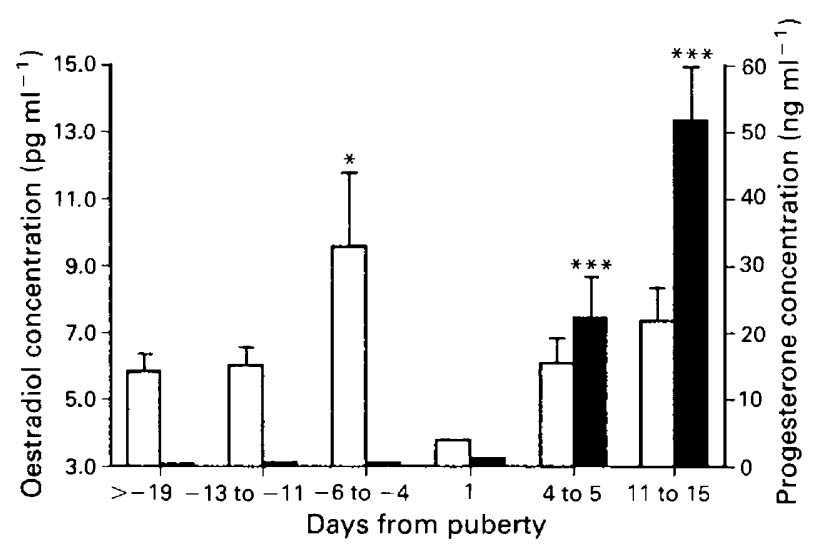

Fig. 4. Variation in concentration of plasma $(\square)$ oestradiol and ( $\square$ ) progesterone in Meishan gilts around puberty. From days -13 to -4 and days 4 to 15 , means were compared with the prepubertal stage $\left(>-19\right.$ days from puberty) and ${ }^{*},{ }^{* * *}: P<0.05$ and $P<0.001$, respectively.

Table 3. Plasma profiles of corticosteroids in Meishan gilts from $I$ to 90 days of age

\begin{tabular}{llll}
\hline & \multicolumn{2}{c}{ Corticosteroid concentration $\left(\mathrm{ng} \mathrm{ml}^{-1}\right)$} \\
\cline { 2 - 4 } group & Morning & Afternoon & Mean \\
\hline & & $53 \pm 4$ & $83 \pm 13^{\mathrm{a}}$ \\
1 & $114 \pm 24$ & $24 \pm 4$ & $33 \pm 3^{\mathrm{b}}$ \\
10 & $41 \pm 4$ & $20 \pm 6$ & $34 \pm 8^{\mathrm{b}}$ \\
20 & $48 \pm 11$ & $37 \pm 10$ & $49 \pm 5^{\mathrm{bb}}$ \\
30 & $60 \pm 2$ & $30 \pm 11$ & $45 \pm 8^{\mathrm{ab}}$ \\
50 & $61 \pm 9$ & $23 \pm 4$ & $37 \pm 4^{\mathrm{b}}$ \\
70 & $51 \pm 6$ & $29 \pm 9$ & $35 \pm 10^{\mathrm{b}}$ \\
80 & $41 \pm 7$ & $34 \pm 8$ & $52 \pm 10^{\mathrm{ab}}$ \\
90 & $70 \pm 13$ & & \\
\hline
\end{tabular}

Values are means $\pm \mathrm{SEM}$.

${ }^{a . b}$ Means within a row with different superscripts are significantly different $(P<0.05)$.

was higher in the morning than in the afternoon $(P<0.01$, Table 3 ). The mean daily concentration decreased between 1 and 10 days of age from $83 \pm 13 \mathrm{ng} \mathrm{ml}^{-1}$ to $30 \pm 4 \mathrm{ng} \mathrm{ml}^{-1}$ $(P<0.05)$ and did not change significantly thereafter.

In Expt 2, there was a similar diurnal variation of the concentration of plasma corticosteroids ( $P<0.01$, Fig. 5 ). The concentration in the morning decreased from $4-6$ days before to $4-5$ days after puberty in comparison with the prepubertal group (Fig. 5).

\section{Discussion}

In the study reported here profiles of $\mathrm{LH}$ in plasma of Meishan gilts were characterized by a high baseline soon after birth, a low frequency of pulses at 10 days of age, a high frequency of pulses at about 50 days, and low amplitude and frequency of 


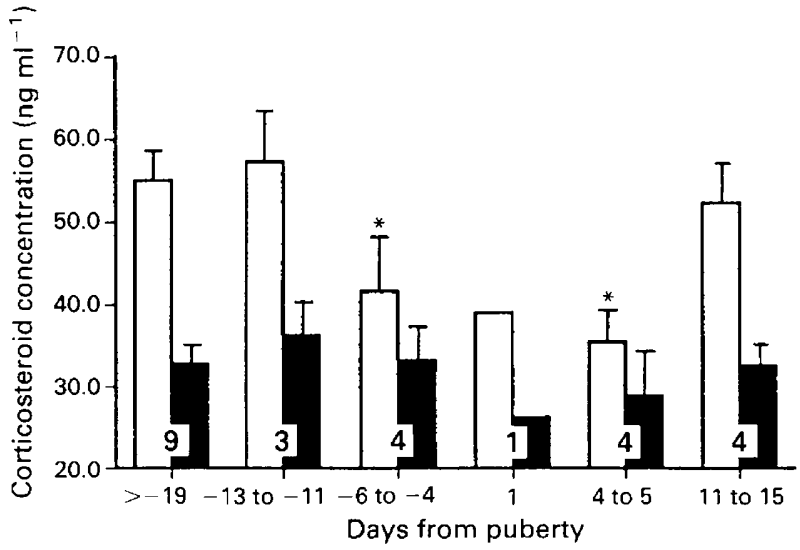

Fig. 5. Variation in morning $(\square)$ and afternoon $(\boldsymbol{~})$ concentrations of corticosteroids in Meishan gilts around puberty. Number of gilts per stage is indicated at the bottom of the bars. From days -13 to -4 and days 4-15, means were compared with the prepubertal stage ( $>-19$ days from puberty) and ${ }^{*} P<0.05$.

pulses between 80 and 90 days. This pattern of variation is similar to that observed in Large White gilts (Camous et al, 1985) even though changes did not take place at the same age.

The observation of high concentrations of LH in plasma shortly after birth also agrees with results obtained in Landrace $x$ Yorkshire piglets of both sexes (Colenbrander et al., 1977). The present study shows that these high concentrations result from high baseline values rather than from high frequency of pulses. A similar period of high $\mathrm{LH}$ secretion around birth has been observed in calves (Challis et al., 1974), guinea-pigs (Donovan et al., 1975), humans (Kaplan and Grumbach, 1976) and rabbits (Berger et al., 1982). A transient period of more frequent pulses during sexual maturation has been observed at later stages (80-120 days of age versus 20-50 days in the Meishan gilts of the present study) in gilts from European breeds attaining puberty at about 170 days (Diekman et al., 1983) or at about 240 days (Camous et al., 1985). In agreement with our previous results in Large White gilts (Camous et al., 1985), the present study shows that the decrease in the frequency of LH pulses is accompanied by a progressive decrease of their amplitude.

In the last 2 weeks preceding puberty, three main phenomena were observed: an increase in LH and in oestradiol concentrations and a decrease in corticosteroid concentration. A higher pulsatility of LH occurred 11-13 days before puberty, whereas mean and baseline concentrations of $\mathrm{LH}$ were increased 4-6 days before puberty. A similar increase in pulsatility and/or in mean hormone concentration was observed during the last 2 weeks before puberty in European gilts by Andersson et al. (1983) and by Lutz et al. (1984), whereas Diekman $e$ et al. (1983) and Diekman and Hoagland (1983) did not observe any significant variation. The increase in baseline values observed in our experiment could reflect a true increase in basal secretion. Alternatively, it is possible that, with the decrease in the amplitude of pulses, their identification was more difficult resulting in an underestimation of pulsatility and overestimation of baseline value. A pattern of high frequency and low amplitude of LH pulses was observed in prepubertal gilts by Beltranena et al. (1993) and was associated with heavier reproductive tracts and a higher secretion of oestradiol than in gilts with more distinct, less frequent, pulses. An increase in LH secretion before puberty has been clearly observed in humans (Boyar et al., 1974; Parker et al., 1975), in rats (Meijs-Roelofs et al., 1983; Urbanski and Ojeda, 1985) and in sheep (Foster et al., 1975; Foster and Ryan, 1981). Our experiments show that mean and baseline concentrations of L.H were still higher during the early luteal phase (4-5 days after puberty) than during the prepubertal stage. At the end of the first luteal phase (11-15 days after puberty), LH secretion was characterized by a distinct pattern of highamplitude, low-frequency pulses as already described in cyclic European or miniature Göttingen sows (Parvizi et al., 1976; Van de Wiel et al., 1981).

After a period of high concentrations, plasma FSH declined progressively between 20 and 80 days of age in our Meishan gilts. A similar decrease during sexual maturation has already been observed in gilts from European breeds (Rayford $e t$ al., 1974; Diekman et al., 1983; Camous et al., 1985) and in other species, such as sheep (Foster et al., 1975), rats (Döhler and Wuttke, 1975) and cattle (Schams et al., 1981). No significant variations in the concentration of plasma FSH were observed during the last weeks preceding puberty in agreement with Diekman et al. (1983). During the early luteal phase, we observed a slight increase in plasma FSH; this is in agreement with results from European gilts during the first oestrous cycle (Ponzilius et al., 1984) and subsequent cycles (Rayford et al., 1974; Van de Wiel et al., 1981).

Relatively high concentrations of oestradiol were observed shortly after birth; this is in agreement with observations in neonatal piglets from European breeds (Ziecik et al., 1990). These oestrogens are probably fetal oestrogens of placental origin that have not yet been eliminated (Ponzilius et al., 1986). The lack of variation in plasma oestradiol concentrations during sexual development up to 1 week before puberty agrees with results obtained in gilts from European breeds (Karlbom et al., 1982; Lutz et al., 1984). However, Schlenker et al. (1973) and Camous et al. (1985) did observe an increase in oestrogen excretion during sexual maturation. In Meishan gilts, the ovaries undergo a period of development between 30 and 60 days of age with the appearance of the first antral follicles and of follicles more than $1 \mathrm{~mm}$ diameter and their multiplication (Cheng, 1983; Prunier et al., 1987; Miyano et al., 1990). This phase of intense ovarian development coincides with that of high LH pulsatility as in gilts from European breeds (Camous et al., 1985). We observed an increase in plasma concentrations of oestradiol 4-6 days before puberty, which probably indicates ovarian stimulation and the beginning of the first follicular phase. The increase in LH secretion observed 4-13 days before puberty was probably the origin of that stimulation.

The high concentration of plasma corticosteroids at birth, the subsequent decline and the lack of variation during the following weeks are comparable to the pattern found in European breeds of pig (Herbein et al., 1977; Kattesh et al, 1990). This perinatal peak is involved in the initiation of parturition (First and Bosc, 1979) and in the induction of hepatic gluconeogenic enzymes that play a role in the energy metabolism of the neonate (Martin et al., 1973). The rapid postnatal decrease in corticosteroid concentrations may be due to changes in the metabolism or synthesis of cortisol in neonatal pigs. Our study shows a significant decrease between morning and afternoon values regardless of age; this reflects the circadian rhythm of 
cortisol profiles. However, at 1 day of age, the decline between morning and afternoon could be simply due to the neonatal process of cortisol decrease. In young pigs from European breeds, it seems that there is no circadian variation at 28 days of age (Evans et al., 1989), although circadian rhythms have been clearly observed in older animals (Whipp et al., 1970; Bottoms et al., 1972; Favre and Moatti, 1977; Evans et al., 1989) but with age-related variations in the timing of peaks and troughs (Evans et al., 1989). Whether the difference in age-related patterns of corticosteroid concentrations between Meishan and European pigs is a true effect of genotype or is a consequence of various environmental conditions remains to be elucidated. Our study shows that the concentration of plasma corticosteroids in the morning decreased shortly before puberty and remained relatively low during the early luteal phase. Few data are available concerning corticosteroid variations during the oestrous cycle. Observations from Esbenshade et al. (1982) did not show any difference between the follicular phase and the early luteal phase, in agreement with our results. The decrease in corticosteroid secretion at the onset of puberty needs further investigation. It could explain the increase in $\mathrm{LH}$ secretion since cortisol has been shown to inhibit LH secretion (Liptrap and Raeside, 1968; Pearce et al., 1988; Estienne et al., 1991). Moreover, a direct effect of cortisol on androgen secretion by thecal cells of the porcine ovary has been demonstrated in vitro (Raeside and Xun, 1986).

The results of our experiments show that four phases, corresponding to those already described in Large White gilts (Camous et al., 1985) can be distinguished during sexual maturation of Meishan females: (i) a perinatal phase characterized by high baseline and low frequency of LH pulses and high FSH concentrations; (ii) an infancy period at about 10 days of age, during which pulsatility of LH is low while FSH concentrations are still high; (iii) a juvenile phase at about 50 days of age, during which, under stimulation due to higher LH pulsatility and the maintenance of high FSH concentrations, antral follicles appear and multiply in the ovaries and (iv) a waiting period between 80 and 90 days of age. Frequency and amplitude of LH pulses as well as FSH concentrations are low presumably owing to the ovarian negative feedback. Increases in LH pulsatility, and in mean and baseline concentrations observed during the 2 weeks before puberty probably stimulate follicular growth and oestradiol secretion leading to the first follicular phase. The decrease in corticosteroids during the last week before puberty may contribute to pituitary or ovarian stimulation or to both. Thus, sexual maturation follows the same pattern in gilts with very different sexual precocity. However, duration of the various phases is shorter in the Meishan breed than in European breeds. The waiting period is particularly variable and is sometimes absent.

The authors wish to thank J. Gauthier, F. Giovanni, J. C. Hulin, J. Lebost, and Y. Peignier for their skilful technical assistance. We also thank S. Camous (Station Centrale de Physiologie Animale INRA, 78350 Jouy en Josas, France) for the gift of anti-porcine LH serum, Y. Combarnous (Station de Physiologie de la Reproduction INRA, 37380 Nouzilly, France) for the gift of purified porcine LH and FSH, G. Hennen (Centre Hospitalier Universitaire, Sart Tilman, Belgium) for the gift of anti-porcine FSH serum and M. Terqui (Station de Physiologie de la Reproduction INRA, 37380 Nouzilly, France) for the gift of anti-oestradiol serum.

\section{References}

Andersson AM, Einarsson S and Edqvist LE (1983) Prepubertal LH, oestradiol. $17 \beta$ and progesterone pattern in gilts Zentralblatt für Veterinärmedizin $A \mathbf{3 0}$ 438-446

Beltranena E, Aherne FX and Foxcroft GR (1993) Innate variability in sexual development irrespective of body fatness in gilts Journal of Animal Science 71 $471-480$

Berger $M$, Jean-Faucher $C$, de Turckheim $M$, Veyssière $G$, Blanc, MR, Poirier JC and Jean C (1982) Testosterone, luteinizing hormone (LH) and follicle stimulating hormone (FSH) in plasma of rabbit from birth to adulthood. Correlation with sexual and behavioral development Acta Endocrinologica 99 459-465

Bottoms GD, Roesel OF, Rausch FD and Akins EL (1972) Circadian variation in plasma cortisol and corticosterone in pigs and mares American Journal of Veterinary Research 33 785-790

Boyar RM, Roffwarg H, Kapen S, Weitzman E and Hellman L (1974) Synchronization of augmented luteinizing hormone secretion with sleep during puberty New England Journal of Medicine $287582-586$

Camous S, Prunier A and Pelletier J (1985) Plasma prolactin, LH, FSH and estrogen excretion in gilts during sexual development Journal of Animal Science $\mathbf{6 0}$ $1308-1317$

Challis JRG, Kim CK, Naftolin F, Judd HL, Yen SSC and Benirschkek K (1974) The concentrations of androgens, estrogens, progesterone and luteinizing hormone in the serum of foetal calves throughout the course of gestation Joumal of Endocrinology 60 107-115

Cheng, PL (1983) A highly prolific pig breed of China. The Taihu breed $P_{i g}$ News and Information 4 407-426

Christenson RK and Ford JJ (1979) Puberty and estrus in confinement reared gilts Joumal of Animal Science 49 743-751

Colenbrander B, Kruip TAM, Dieleman SJ and Wensing CJG (1977) Changes in serum $\mathrm{LH}$ concentrations during normal and abnormal sexual development in the pig Biology of Reproduction 17 506-513

Dantzer $\mathbf{R}$ and Mormède $\mathbf{P}$ (1983) Stress in farm animals: a need for reevaluation Journal of Animal Science 57 6-18

Diekman MA and Hoagland TA (1983) Influence of supplemental lighting during periods of increasing or decreasing daylength on the onset of puberty in gilts Journal of Animal Science 57 1235-1242

Diekman MA, Trout WE and Anderson LL (1983) Serum profiles of LH, FSH and prolactin from 10 weeks of age until puberty in gilts Joumal of Animal Science 56 139-145

Döhler KD and Wuttke W (1975) Changes with age in levels of serum gonadotrophins, prolactin and gonadal steroids in prepubertal male and female rats Endocrinology $97898-907$

Donovan BT, Ter Haar MB, Lockhart AN, Mac Kinnon PCB, Mattock JM and Peddie MJ (1975) Changes in the concentration of luteinizing hormone in plasma during development in the guinea-pig Joumal of Endocrinology 64 521-528

Du Mesnil Du Buisson F and Signoret JP (1962) Influence des facteurs externes sur le déchlenchement de la puberté chez la truie Annales de Zootechnie 11 453-459

Esbenshade KL, Paterson AM, Cantley TC and Day BN (1982) Changes in plasma hormone concentrations associated with the onset of puberty in the gilt Journal of Animal Science 54 320-324

Estienne MJ, Barb CR and Kesner JS (1991) Luteinizing hormone secretion in hypophysial stalk-transected gilts given hydrocortisone acetate and pulsatile gonadotropin-releasing hormone Domestic Animal Endocrinology 8 407-414

Evans FD, Christopherson RJ and Aherne FX (1989) Development of circadian rhythm of cortisol in the gilt from weaning until puberty Canadian journal of Animal Science 68 1105-1111

Favre B and Moatti JP (1977) Dosage des corticostéroides plasmatiques chez le porcelet Annales de la Recherche Vétérinaire 8 111-120

First NL and Bosc MJ (1979) Proposed mechanisms controlling parturition and the induction of parturition in swine Journal of Animal Science 48 1407-1421

Fonda ES, Rampacek GB and Kraeling RR (1984) The effect of adrenocorticotropin or hydrocortisone on serum luteinizing hormone concentrations after adrenalectomy and/or ovariectomy in the prepubertal gilt Journal of Animal Science 114 268-273 
Foster DL and Ryan KD (1981) Endocrine mechanisms governing transition into adulthood in female sheep Journal of Reproduction and Fertility Supplement 30 $75-90$

Foster DL, Lemons JA, Jaffre RB and Niswender GD (1975) Sequential patterns of circulating luteinizing hormone and follicle stimulating hormone in female sheep from early postnatal life through the first estrous cycle Endocrinology $97985-994$

Herbein JH, Martin RJ, Griel LC and Kavanaugh JF (1977) Serum hormones in the perinatal pig and the effect of exogenous insulin on blood sugars Growth $41277-283$

Hughes PE (1982) Factors affecting the natural attainment of puberty in the gilt. In Control of Pig Reproduction pp 93-116 Eds DJA Cole and GR Foxcroft. Butterworths, London

Kaplan SL and Grumbach MM (1976) The ontogenesis of human foetal hormones. Luteinizing (LH) and follicle stimulating hormone (FSH) Acta Endocrinologica 81 808-829

Karlbom I, Einarsson S and Edqvist LE (1982) Attainment of puberty in female pigs: clinical appearance and patterns of progesterone, oestradiol- $17 \beta$ and $\mathrm{LH}$ Animal Reproduction Science 4 301-312

Kattesh HG, Charles SF, Baumbach GA and Gillespie BE (1990) Plasma cortisol distribution in the pig from birth to six weeks of age Biology of the Neonate 58 $220-226$

Killian DB, Kiesling DO, Wulff FP and Stewart ANV (1987) Effects of adrenalectomy and glucocorticoids on puberty in gilts reared in confinement Journal of Animal Science 64 231-236

Le Dividich J, Esnault Th, Lynch B, Hoo-Paris R, Castex Ch and Peiniau J (1991) Effect of colostral fat level of fat deposition and plasma metabolites in the newborn pig Journal of Animal Science 69 2480-2484

Legault C and Caritez JC (1983) L'expérimentation sur le porc chinois en France. I. Performances de reproduction en race pure et en croisement Génétique Sélection et Evolution 15 225-240

Liptrap RM and Raeside JI (1968) Effect of corticotrophin and corticosteroids on plasma interstitial cell-stimulating hormone and urinary steroids in the boar Joumal of Endocrinology 42 33-43

Lutz JB, Rampacek GB, Kraeling RR and Pinkert CA (1984) Serum luteinizing hormone and estrogen profiles before puberty in the gilt Joumal of Animal Science 58 686-691

Martin RJ, Patt JA and Eberhart RJ (1973) The effects of metyrapone and ACTH on the development of gluconeogenesis in the neonatal pig Proceedings of the Society for Experimental Biology and Medicine 144 603-608

Mauléon P (1961) Déroulement de l'ovogénèse comparé chez différents mammifères domestiques Proceedings of the Fourth International Congress on Animal Reproduction (The Hague) 2 348-354

Meijs-Roelofs HMA, Kramer P and Sander HJ (1983) Changes in serum concentration of luteinizing hormone in the female rat approaching puberty journal of Endocrinology $98241-249$

Merriam GR and Wachter KW (1982) Algorithms for the study of episodic hormone fluctuations American Journal of Physiology 243 310-318

Miyano T, Akamatsu J, Kato S and Kanda S (1990) Ovarian development in Meishan pigs Theriogenology 33 769-775

Mormède P and Danzer R (1978) Behavioral and pituitary-adrenal characteristics of pigs differing by their susceptibility to the malignant hyperthemia syndrome induced by halothane anaesthesia. II. Pituitary adrenal function Annales de la Recherche Vétérinaire 9 569-576
Parker DC, Judd HL, Rossman LG and Yen SSC (1975) Pubertal sleep-wake patterns of episodic LH, FSH and testosterone release in twin boys Journal of Clinical Endocrinology and Metabolism 40 1099-1109

Parvizi N, Elsaesser F, Smidt D and Ellendorff F (1976) Plasma luteinizing hormone and progesterone in the adult female pig during the estrous cycle, late pregnancy and lactation and after ovariectomy and pentobarbitone treatment Journal of Endocrinology 69 193-203

Pearce GP, Paterson AM and Hughes PE (1988) Effect of short-term elevations in plasma cortisol concentration on LH secretion in prepubertal gilts Journal of Reproduction and Fertility 83 413-418

Ponzilius KH, Sanford LM, Phillips GD and Palmer WM (1984) Blood hormone changes associated with puberty in the female pig Canadian Joumal of Animal Science 64 177-181

Ponzilius KH, Parvizi N, Elsaesser F and Ellendorff F (1986) Ontogeny of secretory patterns of $\mathrm{LH}$ release and effects of gonadectomy in the chronically catheterized pig fetus and neonate Biology of Reproduction 34 602-612

Prunier A, Caritez JC and Bonneau M (1987) Développement de l'appareil génital des porcs mâles et femelles et évolution de la teneur en androsténone du tissu adipeux des verrats de races européenne ou chinoise Annales de Zootechnie 36 49-58

Raeside JI and Xun HC (1985) Direct effect of cortisol on androstenedione production by thecal cells from porcine ovarian follicles Animal Reproduction Science 12 39-46

Rayford PL, Brinkley HJ, Young EP and Reichert LE (1974) Radioimmunoassay of porcine FSH Journal of Animal Science 39 348-354

SAS (1985) SAS/STAT Guide for Personal Computers, Version 6 Edition. SAS Institute Inc., Cary, NC

Schams DE, Schallenberger E, Gombe S and Karg H (1981) Endocrine patterns associated with puberty in male and female cattle Journal of Reproduction and Fertility Supplement 30 103-110

Schlenker G, Köppe D and Siefert H (1973) Die präpuberale and präovulatorische Oestrogen-ausscheidung in Beziehung zur Fortpflangzungs-regulation weiblicher Schweine Archiv für Experimentelle Veterinärmedizin 27 H.6 881-889

Terqui $M$ and Thimonnier $J$ (1974) Nouvelle méthode radioimmunologique rapide pour l'estimation du niveau de progestérone plasmatique. Application pour le diagnostic précoce de gestation Comptes Rendus des Séances de l'Académie des Sciences, Paris Série D 279 1109-1112

Thibier $M$ and Saumande $J$ (1975) Oestradiol-17 $\beta$, progesterone and $17 \alpha$ hydroxyprogesterone concentrations in jugular venous plasma in cows prior to and during oestrus Journal of Steroid Biochemistry 6 1433-1437

Urbanski HF and Ojeda SR (1985) The juvenile-peripubertal transition period in the female rat: establishment of a diurnal pattern of pulsatile luteinizing hormone secretion Endocrinology $117644-649$

Van de Wiel DFM, Erkens J, Koops W, Vos E and Van Landeghem AAJ (1981) Periestrous and midluteal time courses of circulating LH, FSH, estradiol-17 $\beta$ and progesterone in the domestic pig Biology of Reproduction 24 223-233

Whipp SC, Wood RL and Lyon NC (1970) Diumal pattern of hydrocortisone in plasma of swine American Joumal of Veterinary Research 31 2105-2107

Ziecik AJ, Esbenshade KL. Howard HJ and Britt JH (1990) Sex-related differences in the control of gonadotrophin concentrations in neonatal pigs Animal Reproduction Science 23 123-133 